\title{
Malaysian Affordability Housing Policies Revisited
}

\author{
Diwa Samad ${ }^{1}$, Nurshuhada Zainon ${ }^{1}$, Faizul Azli Mohd Rahim ${ }^{1}$ Eric Lou², Saipol Bari Abd Karim¹ \\ ${ }^{1}$ Department of Quantity Surveying, Faculty of Built Environment, University of Malaya, Malaysia \\ ${ }^{2}$ School of Mechanical, Aerospace, and Civil Engineering, University of Manchester, United Kingdom
}

\begin{abstract}
Housing has always been a significant aspiration of family expression and distinctly priciest investment by household. It plays a momentous role in the country's economy and so central to the societal well-being that is emplaced in the United Nation Universal declaration of Human rights. Yet in developed and developing world alike, cities struggle to provide decent housing for lower and middle income population. The provision of affordable housing is a major policy concern around the world with Malaysia being no exception; rising income hardly keep pace with price hike of housing unit and housing interventions has majorly concentrated on demand side leading to a non- responsive supply sector. Therefore, this paper highlights affordable housing issues pertaining Malaysia. It formulates Malaysian Map of affordability and conducts an evaluation of global housing schemes to better identify policy priorities for Malaysia. It's significant to harmonize supply and demand side factors in the housing market to ensure that housing supply fits the needs of citizens based on the location, price and target group. In case of Malaysia supply oriented initiative are of urgency in short and medium run. This must be supported by long term demand side schemes in parallel. Convergence of these two factors is essential for a balanced equilibrium and obtaining affordability.
\end{abstract}

\section{Introduction}

Housing is decisively rooted in the economic social, and political sphere of any country that it impossible to be explored in isolation from the broader scope of governance and policy. Besides being a remarkably valuable asset, it carries multidimensional significance; It plays an eminent role in accelerating economic growth and it carries social prominence as a spatial locus of personal and familial life (Abd Aziz, Hanif, \& Singaravello, 2011; Keivani \& Werna, 2001)

Despite its multidimensional implications, access to affordable and adequate housing has been an everlasting challenge globally (Beer, 2007). From slum dwellers in the third world cities to middle-income households in affluent global capitals, millions of people are challenged to find affordable housing without financial pressure. The economic and human cost of the housing affordability issue is massive as 330 million households are affected worldwide. Holding the existing trend constant, total households with unsafe and substandard housing or are financially strained by housing expenditures is estimated to reach 440 million - or 1.6 billion people by 2025 (Woetzel, 2014).

Rapid urbanization combined with population growth has incited a surge in housing prices in many urban areas, mainly in developing countries including Malaysia (Buhaug \& Urdal, 2013). This has been supported by the evolution of nuclear families as against extended families brought about by economic development; in 1970 there were 182 households for every 1,000 people, by 2020 there will be 250 households for every 1,000 people (Suraya, 2015). Furthermore, increase in foreigners (expatriate, students and tourists), migration, changing pattern of economic status of the population, change in expectation, and dilapidation of the existing stock has resulted in severe shortage of affordable housing.

Since the Third Malaysia Plan, low cost housing projects has not met its target (Bajunid \& Ghazali, 2012; Ramli, Akasah, \& Masirin, 2014; Shuid, 2009). For instance, throughout the Eighth Malaysia Plan, only 197,649 low cost housing units were built compared to 230,000 units required (Ramli et al., 2014). Although many private developers were involved to offset the housing need, nonetheless, these developers constructed the low-cost houses merely due to quota requirements as they are non-lucrative projects. Residents of low-cost housing continually encounter many challenges such as maintenance, sub-standard 
quality, comfort levels, health, safety and security amenities (Zaid, 2011).

Currently there exist 40 per cent gap between the demand for affordable housing and its supply in the country (Khairie, 2013; Lim, 2015 ). According to the Department of Statistics Housing Income Survey (2014) Malaysian median income stood at RM 4,500 signalling households are unable to afford houses priced higher than RM300, 000 (DOS, 2014). While based on the National Property Information Centre report (2014) only $31.7 \%$ of the housing units built in the year 2014, had a price tag lower than RM 250,000 (NAPIC, $2014 b$ ). Thus, evidently the income pattern of the middle income household finds it challenging to keep pace with the rising cost of housing unit and thereby the need for affordable housing has become more vital than ever before.

In response to this issue, the Malaysian government undertook numerous initiatives to assuage the rising cost through several projects such as Projek Perumahan Rakyat 1 Malaysia (PR1Ma), Projek Rumah Rakyat Miskin Tegar (PPRT), and Skim Myhome Rumah Pertama outlined in $11^{\text {th }}$ Malaysian plan (EPU, 2015). Despite these attempts, Malaysian people still experience a mismatch between acquiring affordable housing and their household income. This is especially so for the middle-income households who are overqualified for the aforementioned low-cost housing programmes and at the same time unable to afford housing by private housing developers.

Though government initiatives has facilitated housing development considerably, housing interventions have focused primarily on demand which subsidizes a non-responsive supply sector. As a result, the housing price is still higher despite the various government subsidies and loans. Relatively less progress is evident in realizing the elements that restrain supply, which probably thwart developments on the demand side.

\subsection{Housing affordability: definitional controversy}

Housing affordability is considered as a household selection decision function between housing and non-housing product expenditure (Suhaida \& Tawil, 2010). Many literatures have acknowledged that housing affordability is a complex phenomenon that is tough to pin down in practice, particularly in terms of defining the suitable geographic scope for housing markets, proper definitions of typical households and individuals, and their changing circumstances. (Gan \& Hill, 2009; Stone, 2008)

Although there exist no standard definition for this term, in its simplest term, housing affordability is denoted as the rent-to-income ratio or houseprice-to-income ratio known as income affordability; more sophisticated measures are purchase affordability, repayment affordability (Gan \&Hill, 2009) and life time income affordability (Abeysinghe \& Gu, 2011). Purchase affordability studies the ability of household to borrow adequate funds for owning a house. Repayment affordability reflects the burden imposed on a household to repay house mortgage. These concepts encompass additional parameters that include down payment ratio, the interest rate, mortgage to- income ratio, and the length of the mortgage (Gan \&Hill , 2009). Studies on income approach includes (Hulchanski, 1995), (Bogdon \& Can, 1997), (Chaplin, 1999), (Bunting, 2004) (Chen, 2010) , (Haffner \& Heylen, 2011). more complicated measures combining residual and income approach are studied by (Skaburskis, 2004) (Gan \& Hill, 2009) (Abeysinghe \& Gu, 2011) (Bramley, 2012), (Heylen \& Haffner, 2013).

\section{Life time income affordability}

The sub-prime mortgage crisis in year 2008 underlined the significance of developing alternative measures addressing long-term housing affordability. Sub-prime lending focused mainly on short-run affordability backed by easy mortgages. Life time income affordability is well established concept under permanent income and life cycle hypothesis which consider the current income added to the discounted present value of expected future income; income includes both labour and non-labour pay (Guest, 2005). In a housing study on Singapore Abeysinghe \& gu (2011) defined life time affordability index as the ratio of lifetime income to house price which indicates informative trends and cycles in housing affordability (Abeysinghe \& Gu, 2011). Despite recent emphasis in the literature on the significance of long-term affordability, this paper could not benchmark it due to data constraints.

\section{The Median Multiple}

In many part of the world definition of affordable housing is centred on the idea of income affordability. According to Demographic international housing affordability survey (2015) the median multiple is a common metric, suggested by the World Bank and the United Nations which rates affordability of housing by dividing the median house price by aggregate annual median household income (Shlomo, 2014). Affordability is rated on a scale of 0 to 5 . The $3.0 x$ median multiple signs that the market delivers a distribution of housing that are subjected to minimal distortions housing supply is responsive and able to match effective demand (Suraya, 2015). 
This study benchmarks median multiplier approach as it has found many literatures and cited by the Housing Buyers' Association as well as in the 11th Malaysia Plan as an appropriate threshold for the affordability of the nation's housing market (EPU, 2015).

\subsection{Malaysian affordability housing: A geographical analysis}

House price has followed an upward pattern in Malaysia even though the Asian financial crisis of 1997 caused majority of high priced housing being left unsold. However during the subsequent plan period, the targets were increased again (Savills, 2008). The resultant excess in supply assisted to retain the prices of relatively moderate houses low thus expedited access to home ownership. Based on UN Habitat's figures 63.4 per cent of households had access to homeownership in 1980s and it reached to a peak of 88 per cent by 1998 (Doling \& Omar, 2012). While from 2000 onwards the Malaysian all-house price has raised steadily and accelerated between 2009 and 2014 (Napic, 20002014); While the all-house price grew at a CAGR (compound annual growth rate) of $5.6 \%$ between 2000 and 2014, between 2009 and 2014, it grew at a CAGR of 10.1\% (2000-2009: 3.1\%) (Suraya, 2015).

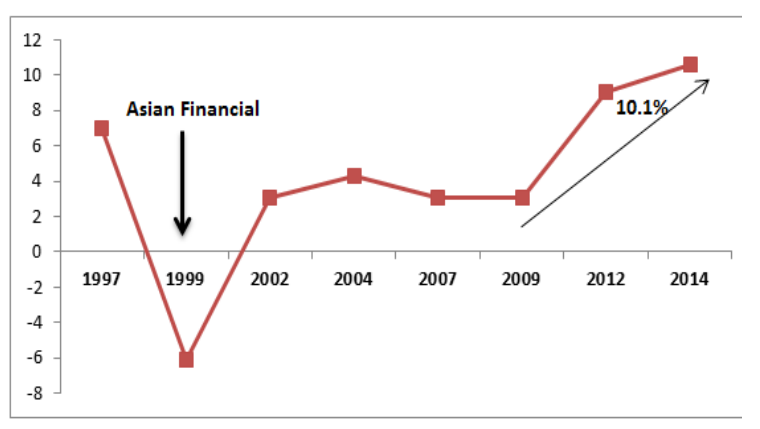

Figure 1: House prices in Malaysia 1997-2014

\section{$\left(\mathrm{CAGR}^{1}\right)$}

Given the Malaysian housing price's trend, the question remains as to whether or not Malaysian housing market is affordable. Further answers lie in the formulated map (Figure2) which indicates the geographical distribution of household incomes versus houses offered in the market, otherwise known as the median multiple. Given the heterogeneity of housing markets with location being a key driver of housing prices, it is best analysed according to different submarkets, segmented into different types and localities (Hashim, 2010). For instance, a terrace house in

\footnotetext{
${ }^{1}$ compound annual growth rate based
}

Sabah was three times more expensive in 2014 compared to 2000, while in Selangor, it has grown twice as expensive (NAPIC, 2014b). In general the median price for the Malaysian housing market exceeds the three times median annual household income threshold for affordability. In 2014, it stood at 4.4 times, and has consistently exceeded 4.0 times from 2002 to 2014 (NAPIC, 2014a).

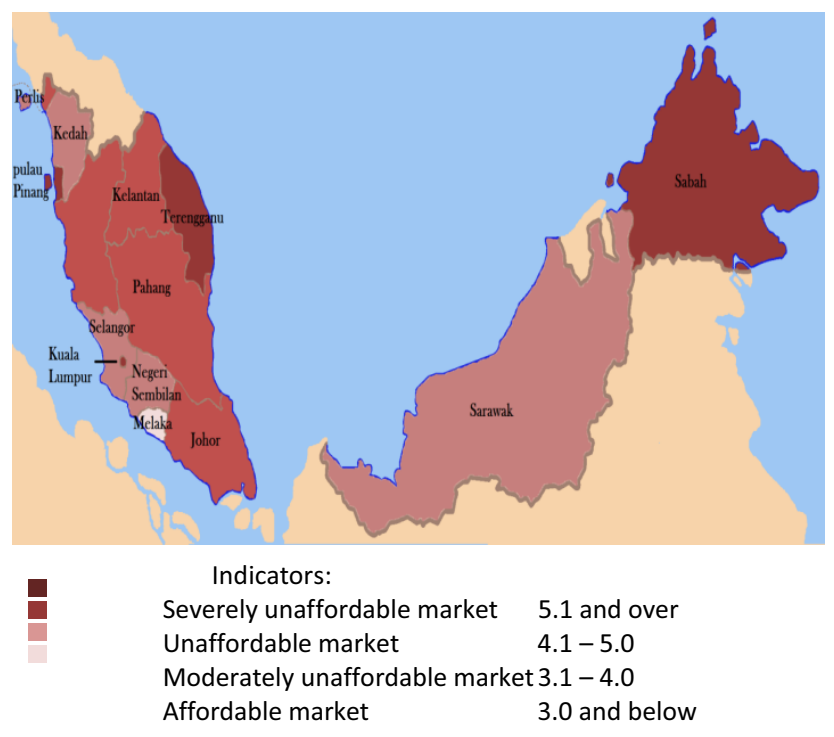

Figure 2: Malaysian Map of Affordability

As highlighted in the figure 2 , Penang and Sabah is above the national statistic whereas Malacca has a median multiple affordability of 3.0. Within the list of state housing markets being assessed, Kuala Lumpur, Pulau Pinang and Sabah stand out as 'severely unaffordable' markets, with median multiples of 5.4 and 5.2 respectively.

One of the reasons behind this extent of unaffordability would be the unresponsiveness of housing supply to effective demand. The lack of houses launched below the three times median multiple prices combined with a high number of high-ended launches contributes towards the severely unaffordable state of housing market (Liew \& Haron, 2013; Teck-Hong, 2012). In 2014, of the new properties launched in Kuala Lumpur there were no properties priced under the RM250,000- RM1 million, with the majority of newly launched properties sited in the RM500,000RM1 million bracket. Given that the three times median multiple price in Kuala Lumpur in 2014 would have been RM274,320, the absence of houses launched below RM250,000 would have skewed the distribution of house prices in the city to the right significantly.

Meanwhile, as highlighted in the map the new housing units launched in Selangor, Negeri Sembilan and Melaka markets are within a more dispersed range of price brackets with a significant 
number of new launches located at or below three times median multiple in Melaka.

\section{Malaysian Housing Schemes}

Following Malaysian Independence in 1957, housing policy primarily concentrated on public housing, mainly directed as a privilege for public sector officials. During just a few years, it mostly focused on the expansion of a home-owning democracy incorporating all segments of the nation envisioning the future development of the country.

Table 1: existing housing schemes in Malaysia

\begin{tabular}{|c|c|c|}
\hline $\begin{array}{l}\text { Schemes/Poli } \\
\text { cies }\end{array}$ & $\begin{array}{l}\text { Objectives/Descrip } \\
\text { tion }\end{array}$ & $\begin{array}{l}\text { Targ } \\
\text { eted } \\
\text { Income }\end{array}$ \\
\hline $\begin{array}{l}\text { Low Cost and } \\
\text { Affordable Public } \\
\text { Housing Program }\end{array}$ & $\begin{array}{l}\quad \text { establish residential } \\
\text { amenities to low income } \\
\text { household as a way to } \\
\text { eradicate poverty and } \\
\text { enhance quality of life }\end{array}$ &, $500<$ RM1 \\
\hline $\begin{array}{c}\text { Projek } \\
\text { Perumahan Rakyat } \\
\text { 1 Malaysia } \\
\text { (PR1MA) }\end{array}$ & $\begin{array}{l}\text { Created to develop } \\
\text { and contain affordable } \\
\text { housing for middle income } \\
\text { household in main urban } \\
\text { hubs. }\end{array}$ & $\begin{array}{r}2,500 \\
\text {-RM7,500 }\end{array}$ \\
\hline $\begin{array}{l}\text { My First Home } \\
\text { Scheme }\end{array}$ & $\begin{array}{l}\quad \text { Purposed to help } \\
\text { young adults who have } \\
\text { newly entered to } \\
\text { workforce to buy their } \\
\text { first residential property. - } \\
\text { Up to } 100 \% \text { financing } \\
\text { from financial institutions. }\end{array}$ & $000^{<\mathrm{RM} 5}$ \\
\hline $\begin{array}{l}\text { MyHome } \\
\text { Scheme }\end{array}$ & $\begin{array}{l}\text { Target low income } \\
\text { group- Encourage private } \\
\text { developer to build lower } \\
\text { cost houses }\end{array}$ & $\begin{array}{l}\quad 2500- \\
6000 \\
\text { (Depend } \\
\text { on } \\
\text { location) }\end{array}$ \\
\hline $\begin{array}{l}\text { Rumah Mesra } \\
\text { Rakyat } 1 \text { Malaysia } \\
\text { (RMR1M) }\end{array}$ & $\begin{array}{l}\text { Target low income } \\
\text { group- } \\
\text { subsidised Government } \\
\text { RM15,000 and RM20,000 } \\
\text { for the low- income group } \\
\text { to create houses valued } \\
\text { between RM45,000 to } \\
\text { RM65,000 }\end{array}$ &, $500<$ \\
\hline
\end{tabular}

Housing strategies were established through a consecutive 5 years agenda. Following the overall objective of "adequate, quality and affordable houses to all Malaysians" the policies have realized that the main problem is not in providing housing for higher income households as their purchasing power attracts private developers to safeguard sufficient supply (Agus, 2002). Rather, the policies have focused on attaining sufficient supply of low cost housing that suit the purchasing power of lower income people. Central to this has been the classification of house price involving a targeted range of dwellings identified (Ubale \& Martin, 2012)

Within this context, the Malaysian government has undertaken numerous measures for expanding home ownership. establishment of CAGAMAS (National Housing Corporation) in 1986 has been a prominent act which is jointly held by the National Bank and private financial bodies and purposed to provide security to those initiating housing loans (CAGAMAS, 2013). Commercial banks stood for about $80 \%$ of housing loans in the 2000s, their businesses is majorly backed by CAGAMAS despite presence of an dynamic private financial sector. Besides, other initiatives ranging from 'Projek Perumahan Rakyat' (PPR) (People's Housing Projects) to My First Home Scheme, Malaysian housing policy has concentrated on either direct provision of low-cost housing, or subsidising the cost of housing for home-buyers.

As portrayed in the table 1, the housing policies have overemphasized the provision of low cost housing that there exist less medium cost house available in the market. Gaps have begun to appear in the system, embodied by the rising concern of middle-income group who are neither entitled for social housing nor capable of affording private sector-supplied houses (Abdullahi \& Aziz, 2011). The challenge is highly prevalent in urban areas: while Malaysian home ownership as a whole stood at $72.5 \%$ in 2010, urban home ownership was $69.1 \%$ and in Kuala Lumpur, it was $53.5 \%$.

\section{Methodology}

This study was conducted during September 2015-January 2016 to gather literature related to affordable housing in Malaysia and worldwide. Plenty of research has been done in different area of this topic; study has emplaced major concentration on policy dimension of the topic. Articles were retrieved from diverse platform which include book chapters, journals, technical reports, institution's database, news and etc. $(\mathrm{N}=70)$. A group of reviewers independently read articles and recorded the main findings on affordable housing policies globally and in Malaysia. The findings are based on the formulated form attached (Appendix). 


\section{Conceptual Framework}

Provision of affordable housing cover property rights, regulation, housing finance, and government subsidies. Based on global policy reviews majority of government's initiative can be categorized into supply or demand side measures. Key words searched are within this framework

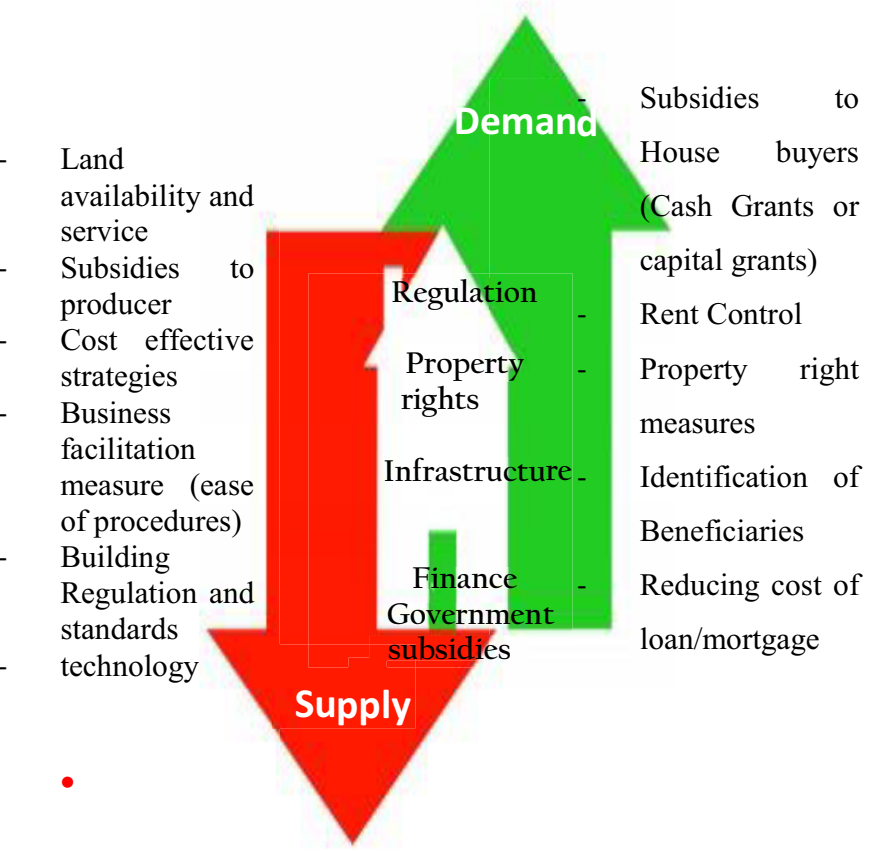

Figure 3: Element of demand and supply side schemes

\section{Discussion and Analysis}

Based on selected literatures key discussion and analysis can be presented in term supply and demand oriented housing schemes.

\subsection{Supply side schemes}

Supply side policy practices mainly encompass land and regulation related issues, minimizing housing development cost and operation and maintenance cost. Countries have adopted various approaches, some are discussed below ${ }^{2}$

A number of countries have successfully developed land base instrument to enhance affordable housing for all income segment; among which transit orient development in Hong Kong, releasing government owned land in Turkey, land regulation to unlock private land in

2 our result does not include the practices in all countries- it's based on selective articles ( there are more than aforementioned countries which might practice it.
Philippine and China, addressing informal land and upgrading land registration methods adopted by Singapore, Japan, South Korea and India are

\begin{tabular}{|c|c|c|}
\hline \multicolumn{3}{|c|}{ 1. Land Related Measures } \\
\hline $\begin{array}{c}\text { Key } \\
\text { strategies }\end{array}$ & $\begin{array}{c}\text { Countrie } \\
\text { s case studies }\end{array}$ & $\begin{array}{l}\quad \text { Rel } \\
\text { ated } \\
\text { studies }\end{array}$ \\
\hline $\begin{array}{l}\text { Transit-oriented } \\
\text { development }\end{array}$ & \begin{tabular}{l}
\multicolumn{2}{c}{ Hong } \\
Kong , New \\
York
\end{tabular} & \multirow{6}{*}{$\begin{array}{l}\text { (Loo \& Chen, } \\
\text { 2010) } \\
\text { (Peterson, } \\
\text { 2006) } \\
\text { (Türel, 2012) } \\
\text { (Deng, } \\
\text { McMillen, \& } \\
\text { Sing, 2012) } \\
\text { (Usavagovitw } \\
\text { ong, Pruksuriya, } \\
\text { \& Mcgranahan, } \\
\text { 2013) } \\
\text { (Lerman, } \\
\text { 2006) }\end{array}$} \\
\hline \begin{tabular}{l}
\multicolumn{1}{c}{ Release } \\
publicly-owned \\
land
\end{tabular} & $\begin{array}{l}\text { Turkey, } \\
\text { China }\end{array}$ & \\
\hline $\begin{array}{l}\quad \text { Land } \\
\text { Regulation } \\
\text { taxation }\end{array}$ & $\begin{array}{l}\text { Philippine } \\
\text {, China }\end{array}$ & \\
\hline $\begin{array}{l}\text { Registration of } \\
\text { land titles }\end{array}$ & Singapore & \\
\hline $\begin{array}{c}\text { Land } \\
\text { adjustment }\end{array}$ & $\begin{array}{l}\text { Japan, } \\
\text { south Korea, } \\
\text { India }\end{array}$ & \\
\hline $\begin{array}{l}\text { Inclusionary } \\
\text { zoning }\end{array}$ & U.S $^{\text {Spain, }}$ & \\
\hline
\end{tabular}

prominent.

For instance Honk Kong has built thousands of homes in the new territories across transportation infrastructure to enhance connectivity and address mismatch between housing and jobs. In places where transit facilities are established, land values have raised accordingly (In Honk Kong land values in the immediate area upsurge by 40-60 per cent) therefore more subsidies will be needed to offset its unaffordability.

Meanwhile in Turkey publicly own lands with strategic locations are released by selling or leasing them for affordable housing development. TOKI housing agency has gathered 4 per cent of urban land through government entities which is developed in partnership with private agencies based on revenue sharing schemes. However despite its bright side, stakeholder involvement is challenging, there might be risk of oversupply and market distortion in price setting. Likewise land registration in Singapore, land regulation and taxation practiced in China and Philippine enforce charges on idle land to minimize speculative land hoarding.

With the exception of property taxes, these instruments do not provide a steady stream of income, but they nonetheless have allowed many cities to fund large investments in infrastructure in the absence of other sources of finance. 


\begin{tabular}{|c|c|c|}
\hline \multicolumn{3}{|c|}{$\begin{array}{l}\text { 2. Cost Effective Housing development (Long } \\
\text { term Supply measures) }\end{array}$} \\
\hline $\begin{array}{c}\text { Key } \\
\text { strategies }\end{array}$ & $\begin{array}{l}\text { Count } \\
\text { ries case } \\
\text { studies }\end{array}$ & $\begin{array}{l}\quad \text { Rel } \\
\text { ated } \\
\text { studies }\end{array}$ \\
\hline $\begin{array}{l}\quad \text { Design } \\
\text { standardization } \\
\text { guidelines }\end{array}$ & $\begin{array}{l}\text { Singa } \\
\text { pore }\end{array}$ & $\begin{array}{l}\text { (Woetzel, } \\
2014)\end{array}$ \\
\hline $\begin{array}{l}\text { Labour skill } \\
\text { building } \\
\text { programs }\end{array}$ & $\begin{array}{l}\text { Malay } \\
\text { sia, India }\end{array}$ & $\begin{array}{l}\text { (Barber, } \\
2004)\end{array}$ \\
\hline $\begin{array}{l}\text { Productivity } \\
\text { improvement } \\
\text { programs }\end{array}$ & $\begin{array}{l}\text { United } \\
\text { State }\end{array}$ & (Hilber, 2015) \\
\hline \begin{tabular}{lr}
\multicolumn{2}{c}{ encourage small } \\
$\quad$ and medium \\
enterprises and \\
Engagement of \\
International firms
\end{tabular} & $\begin{array}{l}\quad \text { Saudi } \\
\text { Arabia, } \\
\text { Egypt , } \\
\text { India }\end{array}$ & $\begin{array}{l}\text { (Rust \& } \\
\text { Koen , 2011) }\end{array}$ \\
\hline $\begin{array}{l}\text { Innovation in } \\
\text { Technology }\end{array}$ & $\begin{array}{l}\text { South } \\
\text { Africa }\end{array}$ & \\
\hline
\end{tabular}

Cost effective housing development measures requires design to value techniques standardization, capital and labour productivity measures. It generates potential savings for an ever lucrative economics of affordable housing that incites developers to consider housing beyond mid- high income customers.

For instance in Singapore using design and standardization guidelines developer can operate at optimum scale through repetitive procedures. However this approach will require customization of regional nuance and customer needs to minimize monotonousness.

Meanwhile in Malaysia labour skill building programs assist in offsetting shortage of skilled labour. Malaysia caught in an interesting dilemma; on one hand there is huge brain drain of young manpower while on the other hand there is severe shortage of skilled workforce especially in construction industry. Therefore the quick and convenient solutions have been importation of foreign labour and adopting labour skill building programs.

Furthermore United State establishes mechanisms that support creativity, innovation as a knowledge sharing platform. This is carried out through training projects, innovation hubs, demonstration programs and etc. However In adopting this policy ability of industries to adopt new approaches should be assessed against cost of setting up the program.

Nonetheless, China, Saudi Arabia, India, Egypt enhanced support for small and medium industry and engage international players in construction industry which serves as a capacity building platform that improve competitive landscape.

South Africa housing policy reviews indicate innovation in material technology that supports expansion of cost-effective and viable construction materials supplying to the affordable housing sector. For effectiveness of this measure it is significant to ensure that developed products are deployed at optimum rather than being an experimental demonstration.

\begin{tabular}{|c|c|c|}
\hline \multicolumn{3}{|c|}{$\begin{array}{l}\text { Maintenance and operation cost (Short Term } \\
\text { Supply measures) }\end{array}$} \\
\hline $\begin{array}{c}\text { Key } \\
\text { strategies }\end{array}$ & $\begin{array}{l}\text { Countr } \\
\text { ies case } \\
\text { studies }\end{array}$ & $\begin{array}{l}\text { Relat } \\
\text { ed } \\
\text { studies }\end{array}$ \\
\hline $\begin{array}{l}\text { Technical } \\
\text { assistance }\end{array}$ & \begin{tabular}{l}
\multicolumn{1}{c}{ Brazil, } \\
United \\
Kingdom
\end{tabular} & \multirow{4}{*}{$\begin{array}{c}\text { (Chavez, } \\
\text { Khemici, Khater, } \\
\text { \& Keshishian, } \\
\text { 2012) } \\
\text { (Clinch \& } \\
\text { Healy, 2000) } \\
\text { (Woetzel, } \\
\text { 2014) } \\
\text { (Iwaro \& } \\
\text { Mwasha, 2010) }\end{array}$} \\
\hline $\begin{array}{l}\text { Energy efficiency } \\
\text { measures }\end{array}$ & \begin{tabular}{l}
\multicolumn{1}{c}{ United } \\
Kingdom , \\
Ireland
\end{tabular} & \\
\hline $\begin{array}{l}\text { Maintenance } \\
\text { quality standards }\end{array}$ & $\begin{array}{l}\text { United } \\
\text { Kingdom }\end{array}$ & \\
\hline $\begin{array}{l}\text { Community } \\
\text { management }\end{array}$ & $\begin{array}{l}\text { United } \\
\text { Kingdom, } \\
\text { China }\end{array}$ & \\
\hline
\end{tabular}

Despite incorporating cost saving mechanism in developing houses, additional cost can be saved in operation and maintenance that accounts for a significant percentage of annual housing expenses. It is relatively fragmented industry with relatively subscale and inefficient operator. By pooling demand for this service, business might be encouraged to scale up.

Minimizing such cost by improving energy efficiency and asset management measures can reduce dilapidation and assist in preserving housing stocks.

For instance in United Kingdom and United State government initiatives have subsidized low income groups to furnish homes with energy saving tools to cut energy cost with a two to one return on investment. Besides, The UK social housing buying consortia, UK decent home criteria are prominent programs.

\subsection{Demand side schemes}

Demand side initiative that is widely adopted by many countries encompasses financial elements, targeted Subsidies, and rental control. Some are discussed below

\begin{tabular}{|c|c|c|}
\hline \multicolumn{3}{|c|}{ 1. Reduce loan/mortgage cost } \\
\hline $\begin{array}{c}\text { Holistic } \\
\text { income assessment }\end{array}$ & India & \\
\hline $\begin{array}{l}\text { Digitized } \\
\text { mortgage } \\
\text { processes } \\
\end{array}$ & China & $\begin{array}{l}\text { (Woetzel, 2014) } \\
\text { (Michael \& } \\
\text { Graham, 2011) }\end{array}$ \\
\hline $\begin{array}{c}\text { Mortgage } \\
\text { liquidity facility }\end{array}$ & sia Malay & $\begin{array}{l}\text { (Leong, 2014) } \\
\text { (Zenou, 2010) }\end{array}$ \\
\hline
\end{tabular}




\begin{tabular}{|c|c|c|}
\hline $\begin{array}{c}\text { Mortgage } \\
\text { backed securities }\end{array}$ & $\begin{array}{c}\text { United } \\
\text { State }\end{array}$ & \\
\hline
\end{tabular}

\begin{tabular}{|c|c|c|}
\hline \multicolumn{2}{|c|}{ 2. } & Leverage collective Saving \\
\hline $\begin{array}{c}\text { Housing } \\
\text { provident funds }\end{array}$ & Singapore & (Woetzel, \\
\cline { 1 - 2 } $\begin{array}{c}\text { Contractual } \\
\text { savings schemes }\end{array}$ & Europe & (Phang S, \\
\hline
\end{tabular}

\begin{tabular}{|c|c|c|}
\hline \multicolumn{3}{|c|}{ 1. Enhance Rental Market } \\
\hline $\begin{array}{l}\text { Rental } \\
\text { Subsidies }\end{array}$ & $\begin{array}{l}\text { United State, } \\
\text { Netherland }\end{array}$ & (Monro, \\
\hline $\begin{array}{l}\text { Renter } \\
\text { protection } \\
\text { measures }\end{array}$ & Germany & $\begin{array}{l}\text { 1997) } \\
\text { (Woetzel, } \\
\text { 2014) }\end{array}$ \\
\hline $\begin{array}{l}\text { Rent to own } \\
\text { initiatives }\end{array}$ & United State & \\
\hline
\end{tabular}

\begin{tabular}{|c|c|c|}
\hline \multicolumn{3}{|c|}{ 2. Identification of beneficiaries } \\
\hline $\begin{array}{l}\text { Eligibility } \\
\text { Database }\end{array}$ & $\begin{array}{l}\text { United } \\
\text { State }\end{array}$ & $\begin{array}{l}\text { (André, } \\
\text { 2010) }\end{array}$ \\
\hline $\begin{array}{l}\text { Prioritization } \\
\text { scheme }\end{array}$ & $\begin{array}{l}\text { United } \\
\text { State }\end{array}$ & $\begin{array}{l}\text { (Y. Chen \& } \\
\text { Sönmez, 2004) }\end{array}$ \\
\hline $\begin{array}{c}\text { Allocation } \\
\text { Mechanism }\end{array}$ & Turkey & \\
\hline
\end{tabular}

\begin{tabular}{|c|c|c|}
\hline \multicolumn{3}{|c|}{ 3. diversify source of funding } \\
\hline $\begin{array}{c}\text { Tax } \\
\text { Increment } \\
\text { Financing }\end{array}$ & United State & $\begin{array}{l}\text { (Ezeanya, } \\
\text { 2004) } \\
\text { (Abdul-Aziz }\end{array}$ \\
\hline $\begin{array}{l}\text { Public private } \\
\text { partnership }\end{array}$ & Malaysia & $\begin{array}{l}\text { \& } \\
\text { 2011) Kassim, }\end{array}$ \\
\hline $\begin{array}{rr}\text { Linkage fee } \\
\text { and taxation }\end{array}$ & United State & $\begin{array}{l}\text { (Woetzel, } \\
\text { 2014) }\end{array}$ \\
\hline
\end{tabular}

For instance in India holistic income assessment is conducted to target significant proportion of unbanked population or informal sector. Meanwhile in China digital and online networks can initiate a widespread access to banking facilities for low-income households and minimize serving cost. For successful implementation of this scheme massive investment in technology, infrastructure, and education is required. In United States costs Mortgage-guarantee schemes are created to minimize the risk to lenders (offer loans with lower interest rate) by safeguarding them in case of any default.

Malaysia creates wholesale loans to banks given their loan portfolios, or secures the portfolios and converts them into government-backed bonds. Although it might cause market distortion, it assists primary market investors in need of long-term funding.

In Singapore housing provident funds initiated mandatory saving scheme in form of social security. It can offer housing loans at below-market interest rates.

United States has established rental control, diversifying source of funding and appropriate system for identification of beneficiary. Meanwhile Malaysia has proposed Public private partnership in diversifying source of fund which required distributing risks along the housing value chain and . It requires public sector competence and skills in management for its effective implementation.

All of the aforementioned schemes require vigilant design for managing systemic risk. And for a longer term and sustainable schemes, it is vital to have a stable macroeconomic setting that can contain inflation. So where is Malaysia in global affordable housing practices? What is the strength and lessons to be learnt?

Although an interplay of supply-side and demand-side schemes are instrumental in the effective provision of affordable housing, in developing countries experiencing rapid growth including Malaysia; when markets are tight, demand-side subsidies might, indeed, intensify the affordability issue for nonsubsidized low-income households as rents or prices increase. Their benefits will then accrue to landlords or developers, with little impact on the overall housing supply. They perform best at markets where they can incite a supply response.

Evidently analysing, based on the tables above, one can realize that Malaysia has undertaken relatively stronger demand side schemes which is highlighted in the global housing policy reviews. Among which access to home financing via mortgage liquidity facility and diversification of fund sources via public private partnership is prominent. Though Malaysia has undertaken tremendous steps in effective provision of housing, less progress has is seen in addressing the factors that constrain supply, which often thwart improvements on the demand side. Therefore cost effective supply side initiatives mainly driving productivity via increasing technology adoption, modernisation of construction methods and reducing reliance on low-skilled workforce, adaptation of IBS (international building standards) and facilitating construction related business procedures are highly recommended.

\section{Conclusion}

This paper reviewed affordable housing issues in Malaysia and formulated map of affordability to enable policy makers to consider strategies targeting issues pertaining particular state or geographical area. This enlightens policy makers to carefully design policies and account for urbanrural variance in affordability.

Drawing on literatures from both developed and developing world, this study attempted to provides 
an overview of the policy schemes that are influential in determining housing market performance. This is done through a supply and demand side policy schemes with the view of safeguarding that policies should reinforce supply and demand side factor toward equilibrium. In case of Malaysia supply oriented initiative are of urgency in short and medium run. This must be supported by long term demand side schemes in parallel. Convergence of this two factors are essential for a balanced equilibrium and obtaining affordability.

Key housing challenge in Malaysia is majorly related to mismatch in demand and supply for affordable housing. Supply side initiatives need more attention in Malaysia mainly in areas related to cost effective housing development measures, maintenance and operation cost and regulation related matters. This paper therefore argues that it is significant to harmonize supply and demand side factors in the housing market to ensure housing supply fits the needs of citizens based on the location, price and target group. Supply and demand side surveys should be conducted in every state to account for regional variations.

\section{References}

1. Abd Aziz, D. W., Hanif, N. R., \& Singaravello, K. (2011). A Study of Affordable Housing within the Middle Income Households in the Major Cities and Towns of Malaysia. Australian Journal of Basic and Applied Sciences, 5(8), 258-267.

2. Abdul-Aziz, A. R., \& Kassim, P. J. (2011). Objectives, success and failure factors of housing public-private partnerships in Malaysia. Habitat International, 35(1), 150157

3. Abdullahi, B. C., \& Aziz, W. N. A. W. A. (2011). The role of private sector participation in achieving anticipated outcomes for lowincome group: A comparative analysis of housing sector between Malaysia and Nigeria. African Journal of Business Management 5(16), 6859-6890.

4. Abeysinghe, T., \& Gu, J. (2011). Lifetime income and housing affordability in Singapore. Urban Studies, 48(9), 1875-1891.

5. Agus, M. R. (2002). The role of the state and market in the Malaysian Housing Sector. Journal of Housing and nthe Built Environment, (17), 49-67.

6. André, C. (2010). A bird's eye view of OECD housing markets. from http://www.iut.nu/Literature/2010/HousingMar ket_inOECDregion_2010.pdfApgar,

7. G., William, C. . (1990). Which Housing Policy Is Best? Housing Policy Debate, 1(1), 1-32.
8. Bajunid, A. F. I., \& Ghazali, M. (2012). Affordable Mosaic Housing: Rethinking LowCost Housing. Procedia-Social and Behavioral Sciences, 49, 245-256.

9. Barber, J. (2004). Skill upgrading within informal training: lessons from the Indian auto mechanic. International Journal of Training and Development, 8(2), 128-139.

10. Beer, A., Kearins, B., \& Pieters, H. (2007). Housing affordability and planning in Australia: the challenge of policy under neoliberalism. Housing Studies, 22(1), 11-24., 22(1), 11-24..

11. Bogdon, A. S., \& Can, A. (1997). Indicators of local housing affordability: Comparative and spatial approaches. Real Estate Economics, 25(1), 43-80.

12. Bramley. (2012). Affordability, poverty and housing need triangulating measures and standards. Journal of Housing and the Built Environment, 27, 133-151.

13. Buhaug, H., \& Urdal, H. (2013). An urbanization bomb? Population growth and social disorder in cities. Global Environmental Change, 23(1), 1-10.

14. Bunting. (2004). The uneven geography of housing affordability stress in Canadian metropolitan areas. Housing Studies 19(3), 361-393.

15. CAGAMAS. (2013). HOUSING THE NATION Policies, Issues and Prospects. from http:/www.cagamas.com.my/sites/default/files /publications/Housing\%20the $\% 20$ Nation $\% 20$ $\% 20$ Policies, \%20Issues\%20and\%20Prospects. pdf

16. Chaplin, R., and Freeman,A. . (1999). Towards an accurate description of affordability. Urban Studies, 36(11), 1949-1957.

17. Chavez, J., Khemici, O., Khater, M., \& Keshishian, P. (2012). Building Codes and Relative Seismic Vulnerability in Latin American Countries. Paper presented at the 15WCEE Lisboa.

18. Chen. (2010). Assessing housing affordability in post-reform China A case study of Shanghai. Housing Studies, 25(6), 877-901.

19. Chen, Y., \& Sönmez, T. (2004). An experimental study of house allocation mechanisms. Economics Letters, 83(1), 137140.

20. Clinch, J. P., \& Healy, J. D. (2000). Domestic energy efficiency in Ireland: correcting market failure. Energy Policy, 28(1), 1-8.

21. Deng, Y., McMillen, D. P., \& Sing, T. F. (2012). Private residential price indices in Singapore: a matching approach. . Regional Science and Urban Economics, 42(3), 485494.

22. Doling, J., \& Omar, R. (2012). Home ownership and pensions in East Asia: The case 
of Malaysia. Journal of Population Ageing, 5(1), 67-85.

23. DOS. (2014). Household Income Survey. from https://www.statistics.gov.my/index.php? $\mathrm{r}=\mathrm{col}$ umn/ctwoByCat\&parent_id=119\&menu_id=a mVoWU54UT10a21NWmdhMjFMMWcyZz0 9

24. EPU. (2015). Providing Adequate and Quality Affordable House- Strategy Paper 6 11th Malaysian Plan.

25. Ezeanya, A. C. (2004). Malaysian housing policy: Prospects and obstacles of national vision 2020. Paper presented at the International conference of Adequate and Affordable Housing for All., Kuala Lumpur Malaysia

26. Gan, Q., \& Hill, R. J. (2009). Measuring housing affordability: Looking beyond the median. Journal of Housing Economics, 18(2), 115-125.

27. Guest, R. S. (2005). A life cycle analysis of housing affordability options for first home owner-occupiers in Australia. Economic Record, 81(254), 237-248.

28. Gyourko, J. (2009). Rethinking Federal Housing Policy How to Make Housing Plentiful and Affordable. HabitatInternational. (2014). Global housing indicators: Evidence for action. from http://www.habitat.org/sites/default/files/gov_ global_housing_indicators.pdf

29. Haffner, \& Heylen. (2011). User costs and housing expenses. towards a more comprehensive approach to affordability. Housing Studies, 26(4), 593-614.

30. Hashim, Z. A. (2010). House price and affordability in housing in Malaysia. Akademika(78), 37-46.

31. Heylen, \& Haffner. (2013). A ratio or budget benchmark for comparing affordability across countries. Journal of Housing and the Built Environment, 28(3), 547-565

32. Hilber, C. A. (2015). UK Housing and Planning Policies: the evidence from economic research. from http://cep.lse.ac.uk/pubs/download/ea033.pdf

33. Hulchanski, J. D. (1995). The concept of housing affordability: six contemporary uses of the housing expenditure-to-income ratio. Housing Studies, 10(4), 471-491.

34. Iwaro, J., \& Mwasha, A. (2010). A review of building energy regulation and policy for energy conservation in developing countries. Energy Policy, 38(12), 7744-7755.

35. Keivani, R., \& Werna, E. (2001). Modes of housing provision in developing countries. Progress in planning, 55(2), 65-118.

36. Khairie, H. (2013). 40\% gap between affordable housing supply and demand. Retrieved 15 December 2015, from http://www.kinibiz.com/story/quotes/45938/\% E2\%80\%9840-gap-between-affordable-

housing-supply-anddemand $\%$ E2\%80\%99.html

37. Leong, c., c. . (2014). Building Sustainable Housing Finance Systems: Malaysian Experience. Paper presented at the 6th Global Housing Finance Conference.

38. Lerman, B. R. (2006). Mandatory inclusionary zoning-the answer to the affordable housing problem. BC Envtl. Aff. L. Rev., 33, 383-394.

39. Liew, C., \& Haron, N. A. (2013). Factors Influencing the Rise of House Price in Klang Valley. International Journal of Research in Engineering and Technology (IJRET), . International Journal of Research in Engineering and Technology (IJRET), 2(10), 261-272.

40. Lim, X. Y., Olanrewaju A.L., Tan S.Y.,. (2015 ). Strategies for Affordable Housing Delivery. Aust. J. Basic \& Appl. Sci., 25(25), 118-124.

41. Loo, B. P., \& Chen, C., \& Chan, E. T. . (2010). Rail-based transit-oriented development: lessons from New York City and Hong Kong. Landscape and Urban Planning, 97(3), 202212.

42. Michael, M., \& Graham, T. (2011). Affordable land and housing in Asia United Nation human settlement program (UN-HABITAT), 2011,.

43. Monro, D. (1997). Public rental housing policy: Learning the lessons from overseas. from

http://www.aph.gov.au/About_Parliament/Parli amentary_Departments/Parliamentary_Library/ pubs/rp/RP9798/98rp06

44. Naoyuki, Y., \& Matthias, H. T., A. . (2015). Housing Policies for Asia: A Theoretical Analysis by Use of a Demand and Supply Model. Tokyo-Japan: Asian Development Bank.

45. Napic. (2000-2014). Property Market Status Report,

2014.fromhttp://napic.jpph.gov.my/portal/web/ guest/publication

46. NAPIC. (2014a). Malaysian House Price Index.

fromhttp://napic.jpph.gov.my/portal/web/guest /publication

47. NAPIC. (2014b). Summary of Existing Stock for Residential, Commercial, Leisure and Industrial property Sub-sector as at Q1-Q4 2013. from http://napic.jpph.gov.my/portal

48. Peterson, G. E. (2006). Land leasing and land sale as an infrastructure-financing option Policy Research Working Paper 4043: World Bank.

49. Phang S, Y. (2007). The Singapore Model of Housing and the WelfareState. from 
http://ink.library.smu.edu.sg/cgi/viewcontent.c gi?article $=1595 \&$ context $=$ soe_research

50. Ramli, A., Akasah, Z. A., \& Masirin, M. I. M. (2014). Factors Contributing to Safety and Health Performance of Malaysian Low-cost Housing: Partial Least Squares Approach. esearch Journal of Applied Sciences, Engineering and Technology, 7(21), 4612.

51. Savills. (2008). Asian Housing Review 2008: Malaysia. Hong Kong. Retrieved 05.01.16, 2016, from http://s3.amazonaws.com/zanran_storage/www .rics.org/ContentPages/40807417.pdf

52. Shlomo, A. (2014). 11th Annual Demographia International Housing Affordability Survey Demographia Stern School of Business, New York University.

53. Shuid, S. (2009). Changing structure of low income housing provision in Malaysia: housing allocation under the computerised Open Registration System (ORS) for low cost house buyer. In H. Conference (Ed.): Cardiff.

54. Skaburskis. (2004). Decomposing Canada's growing housing affordability problem Do city differences matter. Urban Studies, 41(1), 117149.

55. Stone, M. E. (2008). What is Housing Affordability? The Case for the Residual Income Approach. Housing Policy Debate, 17(1), 151-184.

56. Suhaida, M. S., \& Tawil, N. M. H., N. CheAni, A. I. Tahir, M. M. . (2010). A Conceptual Overview of housing affordability in Selangor, Malaysia. International Journal of Social, Behavioral, Educational, Economic, Business and Industrial Engineering, 4(12), 2289-2291.

57. Suraya, I. (2015). making housing Affordable: khazana Research Institute

58. Teck-Hong, T. (2012). Housing satisfaction in medium-and high-cost housing: The case of Greater Kuala Lumpur, Malaysia. Habitat International, 36(1), 108-116

59. Türel, A. (2012). High housing production under less regulated market conditions in Turkey. Paper presented at the ERES 19 thAnnual Conference, Turky.

60. Ubale, M. Y., \& Martin, D. J., \& Seow, T. . (2012). The current practices of the Malaysian formal low cost housing provision system

61. Paper presented at the International Conference of Technology Management, Business and Entrepreneurship Kuala Lumpur Malaysia.

62. Usavagovitwong, N., Pruksuriya, A. A., \& Mcgranahan, G. O. R. D. O. N. (2013). Housing density and housing preference in Bangkok's low-income settlements. In W. Paper (Ed.). Bangkok: International Institute for Enviroment and Development
63. Woetzel, J. R., S. Mischke, J. Garemo, N. Sankhe, S. . (2014). A blueprint for addressing the global affordable housing challenge. Shanghi: McKinsey Global Institute.

64. Zaid, N., Graham, P. (2011). Low-Cost Housing In Malaysia:A Contribution to Sustainable Development? Proc., Energy, Environment and Sustainability, 82-87.

65. Zenou, Y. (2010). Housing policies in China: Issues and options. . Retrieved 01.01.16, from http:/www.ifn.se/wfiles/wp/wp824.pdf 